\title{
PENIMBUNAN BARANG DALAM PERINDUSTRIAN BERDASARKAN PERSPEKTIF EKONOMI ISLAM
}

\author{
HASRIANY HUZAIN \\ Jurusan Perbankan Syariah, Fakultas Ekonomi dan Bisnis Islam, \\ Universitas Islam Negeri Alauddin Makassar \\ Email ; hasrianyhzn048@ gmail.com
}

\begin{abstract}
Abstrak
Menimbunan barang adalah suatu upaya seseorang atau lembaga untuk menimbun barang dagangan, manfaat atau jasa sehingga menjadi langka di pasaran demi mendapatkan keuntungan yang berlipat ganda dan dapat diperkirakan harganya melonjak naik. Kata lainnya disebutkan sebagai Ihtikâr atau monopoli. Perbuatan ihtikar merupakan sebuah penganiayaan terhadap orang lain yang dilakukan secara sengaja untuk memperoleh keuntungan pribadi. Olehkarena itu, praktik bisnis semacam ini akanmenimbulkan mudharat y ang berefek bagi kehidupan masyarakat secara umum. Perilaku ini hukumnya dilarang, meskipun barangkali tingkat keharamannya tentulah berbeda dan tergantung kepada qorenahnya, apakah hal itu menyangkut dhoruriyat, hajjiyat, dan tahsiniyat. Hal itu juga berkaitan erat dengan monopoli dan mengakibatkan dhoiq bagi masyarakat. Muhtakir akan ditimpakan Allah SWT penyakit kusta, Dilaknat, dan kebangkrutan.

Kata kunci : Penimbunan, ikhtiar, monopoli

\section{A. PENDAHULUAN}

Islam merupakan agama yang konprehensif didalamnya terkandung ajaran yang mencakup semua bidang kehidupan mulai dari bidang tauhid, ibadah, munakahat, jinayah, munakahat, warits dan lain-lainnya. Dalam bidang muamalah islam mempunyai bentuk atau prodak tersendiri dimana muamalat Islam berbasiskan ajaran syarieah.
\end{abstract}


Penimbunan barang dalam bahasa Arab disebut Ihtikâr (El-Batani, 2014), yang dipadankan dalam bahasa inggris sebagai monopoly (Ismanthono, 2003) atau monopolistik. Artinya suatu tindakan menguasai pasar sedemikian rupa sehingga dapat merusak mekanisme pasar yang ada. Dengan suatu jenis barang yang dikuasai oleh yang bersangkutan, maka dia dapat mengendalikan harga sekehendaknya. Diantara caranya ialah dengan menimbunnya (menahannya) sehingga barang tersebut langka dipasar. Akibatnya barang tersebut akan naik. Pada praktiknya, Ihtikâr dapat berupa monopoli,oligopoli, atau duopoli. Monopoli terdapat tiga macam bentuk yang terjadi dipasar, yaitu diantaranya:

1. Natural Monopoly, yaitu monopoli yang terjadi secara alamiah atau karena mekanisme pasar murni.

2. Monopoly by Struggle, yaitu monopoli yang terjadi setelah adanya proses kompetisi yang cukup panjang dan ketat melalui situasi dan hambatan.

3. Monopoly by Decree, yaitu proses monopoli yang terjadi karena adanya campur tangan pemerintah yang melakukan regulasi dengan memberikan hak istimewa kepada pelaku ekonomi tertentu untuk menguasai pasar suatu produk tertentu. (Iswardono, 1990).

Rekayasa pasar dalam supply terjadi bila seorang penjual mengambil keuntungan diatas keuntungan normal dengan cara mengurangi pasokan barang komoditas yang dijualnya naik. Ihtikâritu sangat dilarang oleh Agama Islam karena sangat merugikan orang-orang kecil dan hukumnya berdosa. Selain harus mengetahui bagaimana jual-beli yang memang di perbolehkan dan sah menurut hukum Islam juga dituntut untuk tahu apa saja jual-beli yang dilarang oleh Islam, agar tidak terjerumus pada hal yang dilarang oleh Allah SWT, untuk itulah dalam penelitian ini perlu dibahas satu dari sekian banyak jual-beli yang tidak diperbolehkan, yaitu penimbunan barang (Ihtikâr). Tentang apa dan bagaimana penimbunan (Ihtikâr) itusecara detail dalam perspektif hukum ekonomi Islam.

\section{B. PEMBAHASAN}

Penimbunan barang dalam bahasa Arab sepadan dengan Al-Ihtikâr, yang secara terminologi berarti perbuatan menimbun (Poerwadarminta, 1976), pengumpulan barang-barang atau tempat untuk menimbun. Penimbunan barang adalah membeli sesuatu dengan jumlah besar, agar barang tersebut berkurang dipasar sehingga 
harganya (barang yang ditimbun tersebut) menjadi naik dan pada waktu harga menjadi naik baru kemudian dilepas (dijual) ke pasar, sehingga mendapatkan keuntungan yang berlipat ganda. Fiqih Islam mengartikan bahwaal-Ihtikâr bermakna menimbun atau menahan agar terjual (Munawir, 1994). kata Ihtikar berasal dari kata hakarayang berarti az-zulm(aniaya) dan isa ${ }^{\text {ee }}$ ah almueasyarah(merusak pergaulan). Dengan timbangan ihtakara, yahtakiru, ihtikar, kata ini berarti upaya penimbunan barang dagangan untuk menunggu melonjaknya harga.

Apabila pembelian suatu barang di suatu negeri menyebabkan harga barang menjadi mahal dan menyusahkan masyarakat luas, maka itu wajib dicegah, demi menjaga kepentingan umat Islam. Pendek kata, kaidah,,menghindarkan segala hal yang menyusahkan adalah pedoman dalam masalah penimbunan barang.

Ihtikar tidak saja menyangkut komoditas, tapi juga manfaat suatu komoditas, dan bahkan jasa dari para pemberi jasa; dengan syarat "embargo" yang dilakukan para pedagang atau pemberi jasa itu bisa membuat harga pasar tidak stabil, padahal komoditas, manfaat, dan jasa tersebut dibutuhkan oleh masyarakat, negara, dan lain-lain.

\section{Aspek Larangan Menimbun Barang (Ihtikâr)}

Tujuan Ihtikâr yang telah banyak disebutkan diatasmerupakan aspek yang tidak diperbolehkan oleh para fuqoha, berdasarkan dari aspek jenis barang dan waktu penimbunannya yang diharamkan. Imam Al-Ghazali berkata, " ada pun yang bukan makanan pokok dan bukan pengganti makanan pokok, seperti obat-obatan, jamu dan za'faran, tiada sampailah larangan itu kepadanya, meskipun dia itu barang yang dimakan. Adapun penyerta makanan pokok, seperti daging, buah-buahan, dan yang dapat menggantikan makanan pokok dalam suatu kondisi, walaupun tidak mungkin secara terus menerus, maka ini termasuk dalam hal yang menjadi perhatian. Maka sebagian ulama ada yang menetapkan haram menimbun minyak samin, madu, minyak kacang, keju, minyak zaitun, dan yang sejenisnya (Ghazali, 2003).” 
Rasulullah sangat menganjurkan agar umat Islam mendistribusikan sebagian harta dan penghasilan mereka untuk membantu saudara-saudara yang kekurangan dibidang ekonomi. Distribusi yang dimaksud Nabi terbagi menjadi dua jenis yaitu :

a. Distribusi barang dan jasa yang berupa penyaluran atau penyampaian barang tau jasa dari produsen ke konsumen dan para pemakai, artinya sebagai upaya untuk tersalurkannya barang-barang hasil produksi sehingga dapat dikonsumsi oleh masyarakat luas dan orang yang mendistibusikan mendapat laba (hasil) dari penjualan barang yang didistribusikan.

b. Distribusian sebagian harta kepada orang-orang yang membutuhkan sebagai wujud solidaritas sosial, artinya orang yang menyalurkan hartanya tidak mendapatkan pembayaran atau keuntungan (profit) langsung tetapi mendapatkan balasan yang baik atau keuntungan dihari kemudian atau akhirat.

Adapun tujuan distibusi dalam Islam antara lain:

a. Menyatukan hati manusia dalam kebaikan dan kebenaran dari nilainilai ilahi sehingga mereka semakin taan kepada pencipta-Nya.

b. Membersihkan dan menyucikan manuisa dari sifat serakah, tamak, egois dan individualis.

c. Menghindari kegiatan spekulatif kezalimanj dalam distibusi pendapatan dan kekayaan.

Dasar hukum yang digunakan para ulama fiqih yang tidak membolehkan ihtikar/penimbunan barang adalah kandungan nilai-nilai universal Al-Qur'an yang menyatakan bahwa setiap perbuatan aniaya, termasuk didalamnya penimbunan barang diharamkan oleh agama Islam.

Para ulama Syafi'iyah mengatakan bahwa penimbunan barang yang diharankan adalah penimbunan barang-barang pokok tertentu, yaitu membelinya pada saat harga mahal dan menjualnya kembali. Ia tidak menjualnya saat itu juga tapi ia simpansampai harga melonjak naik. Pendapat lain mengatakan bahwa menurut ulama syafi'iyah, hanabillah, Malikiyah, Zaidiyah dan Zahiriyah menurut mereka melakukan penimbunan barang hukumnya haram, alasan yang mereka kemukakan adalah ayat dan hadis-hadis yang telah disebutkan. Menurut Malikiyah penimbunan barang 
hukumnya haram dan dapat dicegah oleh pemerintahm dengan segala cara karena perbuatan itu memberikan mudharat yang besar terhadap kehidupan masyarakat, stabilitas ekonomi masyarakat dan negara.

Penimbunan barang yang dilakukan oleh seseodang dengan tujuan untuk mendapatkan keuntungan dari barang yang ditimbun dan menjualnya dengan harga yang berbeda. Pedagang mendatangkan barang yang dibutuhkan oleh masyarakat dari distributor atau membelinya pada saat harga murah lalu ia menyimpannya karena kebutuhannya atau ia menjualnya kembali saat itu juga apabila itu bukan penimbunan barang pokok sehingga tidak diharamkan. Kebutuhan pokok yang sangat dibutuhkan oleh masyarakat dapat dikatakan penimbunan barang haram apabila bahan poko yangditimbun denga tujuan mencari keuntungan sehingga masyarakat tidak dapat memenuhi kebutuhan hidupnya. Pengharaman terhadap perbuatan penimbunan barang apabila terdapat tiga, yaitu:

a. Barang yang ditimbun harus dibeli terlebih dahulu.

b. Barang yang dibeli merupakan bahan makanan yang dibutuhkan masyarakat.

c. Adanya kesulitan masyarakat untuk mendapatkan bahan makanan yang dibutuhkan

\section{Dasar Hukum Menimbun Barang}

Berdasarkan prinsip hukum Islam barang apa saja yang dibolehkan (halal) Allah SWT untuk memilikinya, maka halal pula bila untuk dijadikan objek perdagangan. Demikian pula dengan segala bentuk yang tidak diperbolehkan (haram) untuk memilikinya maka haram pula untuk memperdagangkannya. Akan tetapi terdapat ketentuan hukum Islam bahwa pada dasarnya barang itu halal, dikarenakan sikap serta perbuatan para pelakunya yang bertentangan dengan syara'maka barang tersebut menjadi haram atau tidak diperbolehkan untuk dimilikinya. Pada umumnya orang memerlukan benda/ barang yang ada pada orang lain untuk dimilikinya, barang tersebut dapat dimilikinya (membeli-pen) dengan mudah tetapi kadang-kadang pemiliknya tidak mau memberikannya (menjual-pen) dengan mudah ia memilih untuk menimbunnya (Ihtikâr). Pemilik barang 
tersebut akan memberikannya (menjual-pen) ketika harga pasaran mulai naik, agar dengan sengaja mendapatkan keuntungan yang lebih besar (Abdullah, et al., 2002).

Berdasarkan ayat Al-Qur'an dan Hadits dapat dipahami bahwa perbuatan penimbunan barang tidak diperbolehkan atau diharamkan sebab merupakan salah satu ancaman kepada orang yang menyimpan ingin membangun dirinya di atas penderitaan orang lain. Ia tidak peduli apakah orang lain itu kelaparan dan tidak berpakaian, yang penting dirinya sendiri mendapatkan keuntungan yang sebesar-besarnya. Jika masyarakat semakin memerlukan barang itu, maka ia makin menyembunyikannya. Ia pun semakin senang jika harga barang-barang itu melonjak semakin tinggi. Manusia sangat berharap terhadap barang yang menjadi kebutuhan primer bagi manusia seperti makanan, lain dengan kebutuhan sekunder

\section{Jenis Prodak Ihtikar}

Menurut Ulama Malikiyah, sebagian Hanabiah, Abu Yusuf, dan Ibn „Abidin (keduanya Hanafiyah)bahwa, ihtikartidak terbatas pada makanan, pakaian, hewan. Tapi seluruh prodak yang diperlukan masyarakat.

Illat (motivasi hukum) ihtikar, adalah"kemudharatan yg menimpa orang banyak". Sementara Imam asy-Syaukani, tidak merinci prodak apa saja, dan tidak membedakan ihtikarapakah pasar dalam stabil atau tidak.

Menurut Fathi al-Duraini: asy-Syaukani mengharamkan ikhtikar pada seluruh benda. Siapa yang melakukan penimbunan barang ditujukan merusak harga pasar, sehingga harga naik secara tajam, maka ia telah berbuat salah.

Mengenai jenis prodak ikhtikar, menurut al-Ghazali adalah hanya terbatas pada bahan makanan pokok. Adapun jenis makanan yang tidak termasuk makanan pokok atau makanan yang tidak membantu atau tidak bisa dijadikan pengganti makanan pokok, itu tidak termasuk objek jenis ikhtikar/ tapi apabila bisa membantu makanan pokok seperti daging dan buah-buahan, itu termasuk jenis objek ikhtikar 
4. Faktor-faktor yang Menyebabkan Terjadinya Penimbunan

Suatu usaha dapat memperoleh keadaan seperti karakteristik penimbunan diatas, karena disebabkan oleh banyaknya hal. Hal-hal yang memungkinkan timbulnya penimbunan/ monopoli pada umumnya adalah:

1. Produsen (penjual-pen) mempunyai hak paten untuk output yang dihasilkan. Seperti hak pengarang, merk dagang, nama dagang.

2. Produsen (penjual-pen) memiliki salah satu sumber daya yang sangat penting dan merahasiakannya atau produsen (penjual-pen) memiliki pengetahuan yang lain daripada yang lain tentang teknis produksi.

3. Pemberian ijin khusus oleh pemerintah pada produsen (penjual-pen) tertentu untuk mengelola suatu usaha tertentu pula.

4. Ukuran pasar begitu kecil untuk dilayani lebih dari satu perusahaan yang mengoperasikan skala perusahaan optimum. Dalam kenyataannya kadang-kadang didapatkan pasar yang hanya mungkin untuk dilayani oleh suatu perusahaan saja yang mengoperasika skala produksi optimum, misalkan dalam bidang transportasi, listrik dan komunikasi. Pasar monopoli yang muncul sering disebut dengan monopoli alami (natural monopoly).

5. Pemerintah menetapkan kebijaksanaan pembatasan harga (limit pricing policy). Kebijaksanaan pembatasan harga (penetapan harga pada satu tingkat yang serendah mungkin) dimaksudkan agar supaya perusahaan baru tidak ikut memasuki pasar. Kebijaksanaan harga biasanya dibarengi juga dengan kebijaksanaan promosi penjualan secara besar-besaran (Fathorrazi, et al., 2012).

Penimbunan barang merupakan halangan terbesar dalam pengaturan persaingan dalam pasar Islam. Dalam tingkat internasional, menimbun barang menjadi penyebab terbesar dari krisis yang dialami oleh manusia, yang mana beberapa negara kaya dan maju secara ekonomi menimbun produksi, perdagangan, bahan baku kebutuhan pokok. Bahkan, negara-negara tersebut menimbun pembelian bahan-bahan baku dari negara yang kurang maju perekonomiannya lalu negara tersebut menimbun penjualan komoditas industri yang dibutuhkan oleh negara-negara tadi. Hal itu menimbulkan bahaya besar terhadap keadilan distribusi kekayaan dan pendapatan dalam tingkat dunia. Jika dikaitkan dengan kehidupan 
sosial, maka praktik Ihtikâratau monopoli dalam dunia bisnis tentu akan berdampak pada macetnya sendi-sendi ekonomi. Sehingga seolah-olah orang yang miskin akan sangat susah keluar dari komunitas kemiskinannya. Menyikapi praktik monopoli, Abdul Manan, dalam buku Islamic Ekonomic theory and practice berpendapat, Negara Islam mempunyai hak untuk mengontrol dan mengatur harga dan keuntungan. Dengan demikian, maka harga-harga maksimum dapat diatur. Penyebab utama tindakan Ihtikâratau monopoli seseorang adalah karena egoisme dan kesesatan hati terhadap hamba Allah. Karena orang yang mempraktikkan hal tersebut ingin meluaskan kekayaannya dengan cara mencekik orang lain (merugikan orang lain) (Konsep Monopoli Dalam Tinjauan Ekonomi Islam, 2013).

Penimbunan barang mengakibatkan adanya inflasi. Dalam ilmu ekonomi, inflasi adalah suatu proses meningkatnya harga-harga secara umum dan terusmenerus (kontinu) berkaitan dengan mekanisme pasar yang dapat disebabkan oleh berbagai faktor, antara lain konsumsi masyarakat yang meningkat, berlebihnya likuiditas di pasar yang memicu konsumsi atau bahkan spekulasi, sampai termasuk juga akibat adanya ketidak lancaran distribusi barang karna adanya penimbunan barang (Ihtikâr). Dengan kata lain, inflasi juga merupakan proses menurunnya nilai mata uang secara kontinu. Inflasi adalah proses dari suatu peristiwa, bukan tinggirendahnya tingkat harga. Artinya, tingkat harga yang dianggap tinggi belum tentu menunjukan inflasi. Inflasi merupakan petunjuk untuk melihat tingkat perubahan, dan dianggap terjadi jika proses kenaikan harga berlangsung secara terus-menerus dan saling pengaruh-memengaruhi. Istilah inflasi juga digunakan untuk mengartikan peningkatan persediaan uang yang kadangkala dilihat sebagai penyebab meningkatnya harga. Inflasi dapat digolongkan menjadi empat golongan, yaitu inflasi ringan, inflasi sedang, inflasi berat, dan hiperinflasi. Inflasi ringan terjadi apabila kenaikan harga berada di bawah angka $10 \%$ setahun; inflasi sedang antara 10\%-30\% setahun; berat antara 30\%-100\% setahun; dan hiperinflasi atau inflasi tak terkendali terjadi apabila kenaikan harga berada di atas $100 \%$ setahun. Penyebab inflasi dapat disebabkan oleh dua hal, yaitu tarikan permintaan (kelebihan likuiditas/ uang/ alat tukar) dan yang kedua adalah desakan (tekanan) produksi dan/ atau distribusi (kurangnya produksi (product or service) dan/ atau juga termasuk kurangnya distribusi) (Sukirno, 2004). 


\section{Ekonomi Dan Keuntungan}

Di dalam proses ekonomi merupakan suatu keharusan apabila para pelakunya menginginkan keuntungan. Islam tidak menafikan hal itu, hal ini dapat dilihat dari adanya konsep riba dalam Islam itu sendiri. Doktrin tersebut secara inplisit dapat difahami bahwa didalamnya mengindikasikan adanya suatu bentuk keuntungan. Hanya saja keuntungan yang ingin diperoleh hendaknya tidak bertendensikan eksploitasi dan ketidakwajaran. Untuk menghindari hal itu Allah menurunkan ayat Al-Qur'an (QS.2: 275) yang artinya, 'Allah menghalalkan jual beli dan mengharamkan riba". Dengan kata lain firman-Nya itu menegaskan bahwa praktik mencari keuntungan melalui jalan riba tidaklah sama dengan mencari keuntungan dengan cara yang wajar yaitu, jual beli. Oleh sebab itu cara riba dan cara jual beli sama sekali berbeda. Di samping itu, juga dapat difahami bahwa ayat tersebut menunjukan bahwa manusia selaku makhluk sosial, ia tidak dapat berdiri sendiri di dalam memenuhi kebutuhan hidupnya. Untuk itulaherlaku proses perdagangan di antara sesamanya agar satu sama lain saling melengkapi.

\section{KESIMPULAN}

Jenis penimbunan yang dilarang mengenai segala jenis makanan. Adapun yang bukan makanan dan bukan yang termasuk makanan pokok, seperti obatobatan, jamujamuan, za'faran dan lain sebagainya, maka tiada sampailah larangan itu kepadanya, meskipun dia itu barang yang dimakan. Menimbun itu dilarang apabila terdapat syaratsyarat tertentu di antaranya barang yang ditimbun tersebut merupakan barang bahan pokok makanan yang berupa sembako, yang dimaksud adalah kebutuhan manusia pada setiap harinya untuk dikonsumsi atau bisa disebut untuk dimakan. Kecuali minyak, obatobatan. Akan tetapi obat-obatan dapat pula dilarang ditimbun apabila ada seseorang yang sangat membutuhkannya untuk atau demi kesehatan tubuhnya yang sakit. Minyak dapat pula ditimbun melainkan bukan makanan pokok yang tidak dibutuhkan setiap saatnya dan dalam jangka waktu cukup panjang dapat pula disimpan untuk dipergunakan dikala dibutuhkan nanti. Sedangkan dalam makanan pokok setiap manusia sagat membutuhkannya dan setiap saat dibutuhkan untuk dikonsumsinya. Jadi dengan kata lain jenis barang yang dilarang ditimbun adalah berupa makanan pokok. Ternyata terdapat 
beberapa faktor yang menyebabkan terjadinya penimbunan barang (Ihtikâr). Selain dari kebijakan pemerintah (UU) terdapat pula faktor yang lain berupa keistimewaan dari suatu barang yang dihasilkan tersebut atau bahkan dari suatu produsen tersebut memiliki hak paten yang dapat digunakan untuk menimbun suatu barang tersebut. Faktor-faktor tersebut tidak hanya yang merugikan (negatif) akan tetapi terdapat pula yang menguntungkan bagi negara (positif).

Tindakan menimbun barang (Ihtikâr) menyebabkan krisis yang sangat fatal dan sangat mengancam stabilitas ekonomi. Ihtikâr juga menyebabkan kesulitan bagi orang lain serta menyempitkan ruang gerak mereka untuk memeperoleh kebutuhannya. Ihtikâr bisa juga berakibat pada kelangkaan suatu barang, ini berarti membuat barang yang sudah ada menjadi jarang. Penimbunan barang merupakan halangan terbesar dalam pengaturan persaingan dalam pasar Islam. Dalam tingkat internasional, menimbun barang menjadi penyebab terbesar dari krisis yang dialami oleh manusia, yang mana beberapa negara kaya dan maju secara ekonomi menimbun produksi, perdagangan, bahan baku kebutuhan pokok. 


\section{DAFTAR PUSTAKA}

Abdullah, Sohari Sahrani dan Ru'fah. 2002. Fikih Muamalah. Bogor : Ghalia Indonesia, 2002.

El-Batani, Rian Hidayat. 2014. Kamus Pengatahuan Islam Lengkap. Depok : Mutiara Allamah Utama, 2014.

Fathorrazi, Tati Suhartati Joesron dan M. 2012. Teori Ekonomi Makro.

Yogyakarta : Graha Imu, 2012.

Ghazali, Imam. 2003. Hukum Perjanjian Islam. Jakarta : pustaka Nasional, 2003.

Ismanthono, Henricus W. 2003. Kamus Istilah Ekonomi Populer. Jakarta :

Kompas, 2003.

Iswardono. 1990. Ekonomi Mikro. Yogyakarta : UPP AMP YKPN, 1990.

Konsep Monopoli Dalam Tinjauan Ekonomi Islam. Aji, Didik Kusno. 2013. 1, 2013, Jurnal Adzkiya, Vol. 1.

Munawir, Ahmad Warson. 1994. Kamus Al-Munawwir. Yogyakarta : Unit Pengadaan Buku Pondok Pesantren Al-Munawwir, 1994.

Poerwadarminta, WJS. 1976. Kamus Umum Bahasa Indonesia. Jakarta : Balai Pustaka, 1976.

Sukirno, Sadono. 2004. Teori Pengantar Makro Ekonomi. Jakarta : PT Raja Grafindo Persada, 2004. 